\title{
The Use of Biodiesel in Diesel Engines
}

\author{
S. Chuepeng \\ Kasetsart University \\ Thailand
}

\section{Introduction}

Biodiesel has been increasingly used in diesel engines as a neat or partial substitute with diesel within the past few decades. It is mainly due to its comparable properties to those of diesel, environmental concerns, and energy security. This chapter describes impacts of the use of biodiesel as a fuel for diesel engines, collected from previous research work recently published in journals, proceedings, or other references involved.

\subsection{Advantages of biodiesel use in diesel-powered vehicles}

Promotions to use alternative bio-fuels in transportation and environmental concerns on carbon dioxide $\left(\mathrm{CO}_{2}\right)$ emissions are the main reasons for instigating the use of biodiesel as an alternative fuel for compression ignition (CI) engines (usually known as diesel engines). Presently, vehicles currently circulated in Europe and other countries are fuelling with low percentage of biodiesel without problem, due to a consequence of technological advances. In Europe, there is a European Union (EU) Directive to promote the use of bio-fuels for transportation (Directive 2003/30/EC, 2003) with an objective of increasing use of bio-fuels towards $\mathrm{CO}_{2}$ emission reduction in transportation.

As one among other bio-fuels, biodiesel is considered to be $\mathrm{CO}_{2}$ neutral in terms of the global carbon cycle (Quirin et al., 2004). In the production aspect, the cost for bio-fuel for transportation is normally higher than those of conventional fossil fuels. However, there are benefits of biodiesel in the view of environment, not just conserving fossil fuel resources. Other distinctive advantages comprise near-zero sulphur content in the fuel and its combustion emissions, superior capability of biological degradation in aquatic environment, and a reduction in greenhouse effect gas due to a more favourable energy and $\mathrm{CO}_{2}$ balance over the full life cycle (Camobreco et al., 2000). The latter revealed that overall energy used with soybean-based biodiesel production (feedstock production, feedstock transportation, conversion, fuel transportation) and use (combustion in a diesel engine) will drop by $74 \%$ compared to fossil diesel. Though, this report makes no account between $\mathrm{CO}_{2}$ fixation by the soybean crop and the use of land for farming.

In addition, the Commission Green Paper (CEC, 2000) described an ambitious EU programme that has set a target of $20 \%$ alternative fuel substitution in conventional fuel in the road transport sector by the year 2020. However, for compliance to the relevant legislation on emission standards, the EU Directive suggests that high proportion blends $(>5 \% \mathrm{v} / \mathrm{v})$ of biodiesel used in non-adapted vehicles should be monitored. 


\subsection{Emission regulation and controls}

Diesel engines are normally encounter with combustion noise, engine vibration, and the problem of nitrogen oxides $\left(\mathrm{NO}_{\mathrm{x}}\right)$ - particulate matter $(\mathrm{PM})$ trade-off emissions. The latter is considered to impact in global part while world emission legislations are increasingly stringent. Table 1 shows an example of the EU emission standards for heavy-duty diesel engines since EURO I which came into force in 1992.

\begin{tabular}{|l|c|c|c|c|c|c|c|}
\hline \multirow{2}{*}{ Tier } & \multirow{2}{*}{ Year } & $\mathrm{CO}$ & $\mathrm{HC}$ & $\mathrm{NO}_{\mathrm{x}}$ & $\mathrm{PM}$ & Smoke & \multirow{2}{*}{ Test Method } \\
\cline { 3 - 8 } & & $\mathrm{g} \cdot \mathrm{kW}^{-1} \cdot \mathrm{h}^{-1}$ & $\mathrm{~g} \cdot \mathrm{kW}^{-1} \cdot \mathrm{h}^{-1}$ & $\mathrm{~g} \cdot \mathrm{kW}^{-1} \cdot \mathrm{h}^{-1}$ & $\mathrm{~g} \cdot \mathrm{kW}^{-1} \cdot \mathrm{h}^{-1}$ & $\mathrm{~m}^{-1}$ & \\
\hline \multirow{2}{*}{ EURO I } & $1992(<85 \mathrm{~kW})$ & 4.5 & 1.1 & 8.0 & 0.612 & & ECE R-49 \\
\cline { 2 - 9 } & $1992(>85 \mathrm{~kW})$ & 4.5 & 1.1 & 8.0 & 0.36 & & ECE R-49 \\
\hline \multirow{2}{*}{ EURO II } & 1996 & 4.0 & 1.1 & 7.0 & 0.25 & & ECE R-49 \\
\cline { 2 - 9 } & 1998 & 4.0 & 1.1 & 7.0 & 0.15 & & ECE R-49 \\
\hline EURO III & 2000 & 2.1 & 0.66 & 5.0 & 0.1 & 0.8 & ESC and ELR \\
\hline EURO IV & 2005 & 1.5 & 0.46 & 3.5 & 0.02 & 0.5 & ESC and ELR \\
\hline EURO V & 2008 & 1.5 & 0.46 & 2.0 & 0.02 & 0.5 & ESC and ELR \\
\hline EURO VI & 2013 & 1.5 & 0.13 & 0.4 & 0.01 & & ESC and ELR \\
\hline
\end{tabular}

Table 1. EU emission standards for heavy-duty diesel engines (Source: www.dieselnet.com)

Researchers have made efforts to reduce pollutant and greenhouse gases emitted from engines. A number of approaches have been conducted and developed since internal combustion (IC) engines were invented. Nowadays, clean diesel engine technologies have been introduced and widely used such as (1) fuel and additives, (2) in-cylinder technology, (3) lubricant oil, and (4) exhaust gas after-treatment devices.

In the view of fuel technology, biodiesel fuels in forms of ethyl or methyl esters have been proven to lower hydrocarbon $(\mathrm{HC})$, carbon monoxide $(\mathrm{CO})$, and PM but generating higher $\mathrm{NO}_{x}$ emissions (Graboski \& McCormick, 1998; Lapuerta et al., 2008) when combusted in diesel engines. A synthetic gas-to-liquid (GTL) (as well as X-to-liquid) fuel derived by the FischerTropsch method has been introduced to increasing numbers of countries. The synthetic diesel fuel properties are comparable to those of fossil diesel but higher cetane number, lower sulphur, and lower aromatic hydrocarbons (Oguma et al., 2002). The combustion of synthetic diesel improves fuel consumption and emissions, i.e. $\mathrm{NO}_{\mathrm{x}}, \mathrm{PM}, \mathrm{CO}$, and $\mathrm{HC}$, compared to fossil diesel. Such reported problems e.g. sliding part lubricity, seal material compatibility, and low temperature flowability can be improved with additives (McMormick et al., 2002). In the past decades, hydrogen as a gas has been tested and substituted diesel in the IC engines. It contains no carbon and therefore does not produce $\mathrm{CO}_{2}$. The addition of hydrogen to the main fossil diesel was favorably reported in terms of brake power, thermal efficiency, and reduction of $\mathrm{HC}, \mathrm{CO}, \mathrm{CO}_{2}$, and PM emissions (Kumar et al., 2003).

In-cylinder fuel injection system is one of the effective strategies in reducing emissions from diesel engines (Mahr, 2002). For the engine induction system, both fresh air and exhaust gas recirculation (EGR) was proven to reduce $\mathrm{NO}_{x}$ emissions. Yet another charging system, variable geometry turbocharger (VGT) can recently provide acceleration for a wide range of load and speed (Filipi et al., 2001). Furthermore, new combustion concepts, i.e. multiple stage diesel combustion (MULDIC) (Hashizume et al., 1998), late fuel injection strategies (Kimura et al., 2001), premixed diesel combustion (PREDIC) (Klingbeil et al., 2003), homogeneous charge compression ignition (HCCI) (Ibara et al., 2006), and partially 
premixed compression ignition engines (PPCI) (Weall \& Collings, 2007) have been tested and some of them are in markets today.

Auxiliary emission control devices makes possible an optimisation between fuel consumption (in term of thermal efficiency) and $\mathrm{NO}_{\mathrm{x}}-\mathrm{PM}$ trade-off emissions, thank to the advent of new control technologies. Examples of after-treatment techniques are diesel oxidation catalysts (DOC), diesel particulate filters (DPF), $\mathrm{NO}_{x}$ adsorber catalyst (NAC), and selective catalytic reduction (SCR). These come into common use nowadays.

\subsection{Diesel engine operation}

Diesel engine operates at high compression ratios as only air is inducted into the cylinder and compressed. Fuel and air are therefore mixed internally (Ferguson, 1986). The injection process of a high pressurised fuel takes place under high temperature compressed air condition in the cylinder near the end of the compression stroke. This fuel jet atomises into droplets, evaporates, and entrains in the compressed air to form a combustible charge. At that time, the air temperature and pressure are beyond the fuel's ignition point, and after a short delay, auto-ignition of the fuel-air mixer spontaneously initiates the combustion process. This concomitantly occurs in all over the combustion chamber unlike propagated flame in the spark ignition (SI) engine (gasoline or petrol engine).

The overall diesel combustion process described in Heywood (1988) can be summarised here by identifying in a typical heat-release-rate diagram of a direct injection engine with one injection per engine cycle as shown in Fig. 1. This may differ from that of multiple injection engines such today's engines with common rail fuel injection system. Ignition delay is the period between the start of fuel injection (SOI) into the combustion chamber and the start of combustion (SOC). The phase of rapid combustion of the premixed fuel with air under the flammability limit during the ignition delay period is called premixed combustion, resulting in the high heat-release rate characteristics of this phase. Subsequently, mixing-controlled combustion phase occurs once the fuel-air pre-mixture during the ignition delay has been consumed. The burning rate is controlled in this phase primarily by the fuel vapour-air mixing process and the heat release rate is controlled by the mixture becoming available for burning. Late combustion is the phase well into the expansion stroke that heat release continues in low rate, due to a small fraction of the fuel yet has not been burnt, promoting more complete combustion.

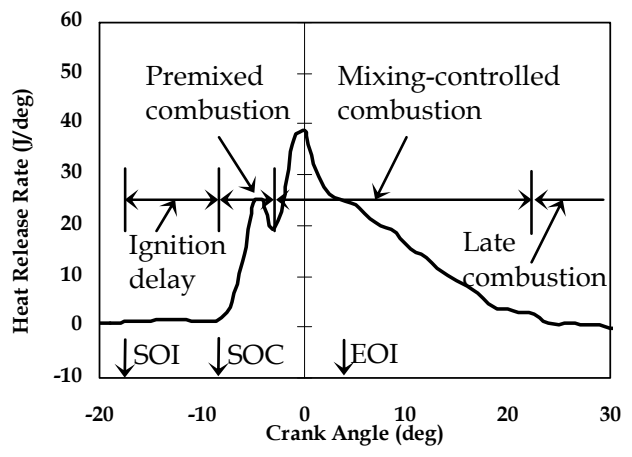

Fig. 1. Typical heat release rate diagram of direct injection engine identifying diesel combustion phase (Heywood, 1988, with modification) 
In the expansion stroke, the exhaust valves start to open about two-third of the way. At this time, the blow-down process takes place as the cylinder pressure is higher than the exhaust manifold pressure. The piston simultaneously pushes the burned gases out of the cylinder during exhaust stroke through the valves, into exhaust port and manifold. Just before top dead centre (TDC), the intake valves open while the exhaust valves close just after TDC; this is called valve overlapping. The next cycle starts again.

\subsection{Diesel fuel injection}

Just about to reach TDC in the compression stroke, the fuel is injected into the cylinder of a diesel engine by high pressure pump through a nozzle orifice. High injection pressures ranging from 200 to 2,000 bar, depending on specific combustion strategies, are required. This is as the injected liquid fuel jet enters the combustion chamber at high velocity to atomise the fuel into droplets for rapid evaporation and to traverse the combustion chamber in a short time for fully utilising the air charge.

It is necessary to develop the fuel injection pump to serve increasing demands for fuel injection systems (Bosch, 2005) as well as the tightening exhaust gas emission standards. The followings are common types of fuel injection pump systems.

a. Distributor injection pumps with mechanical and electronic governors producing injection pressures up to 700 bar, especially popular in high-speed diesel engines for passenger cars and light-duty trucks.

b. In-line injection pumps with mechanical governors or electronic actuators timing devices producing injection pressure up to 1,150 bar, generally used for commercial vehicles and stationary engines.

c. Single-plunger injection pumps, directly actuated by the engine's camshaft with injection pressure up to 1,500 bar, usually used with large marine engines, construction machinery and low displacement engines.

d. Unit injector-pump system, commonly employed in commercial vehicles and passenger cars with injection pressures up to 1,500 bar.

e. Common rail injection system, fully equipped with sensors and actuators.

For the common rail fuel injection system, the injection pressure and timing are independent (Flaig et al., 1999). The injection timing is controlled by an engine electronic control unit (ECU) which can communicate with a fast control area network (CAN). This can be applied to both naturally aspirated and turbocharged engines. Additionally, hydraulic actuation of conventional pump-line-injector fuel systems can be eliminated. By this manner, multiple injections within an engine cycle are enabling. Therefore, engine torque and noise levels can be potentially improved.

\section{Biodiesel production}

Biodiesel production from oil-bearing crops, animal fats, and waste cooking oils is literary investigated. These include several operating parameters (e.g. feedstock, catalyst, techniques, etc.) which impact on biodiesel production processes, i.e. transesterification and esterification reactions. Selected fuel standards for biodiesel are gathered and presented.

\subsection{Biodiesel production techniques}

Biodiesel is oxygenated compounds, defined as the mono alkyl esters of long chain fatty acids derived from lipid feedstock for example, vegetable oils, animal fats, or even waste 
cooking oils. Biodiesel can be used in diesel engines as some of its key properties are similar to those of fossil diesel. However, pure oils are unsuitable for diesel diesel due to being a cause of carbon deposit and pour point problems (Graboski \& McCormick, 1998). Additionally, they can also lead to engine problems, e.g. long-term engine deposit, injector plugging, or lube oil gelling (Kalam \& Masjuki, 2005).

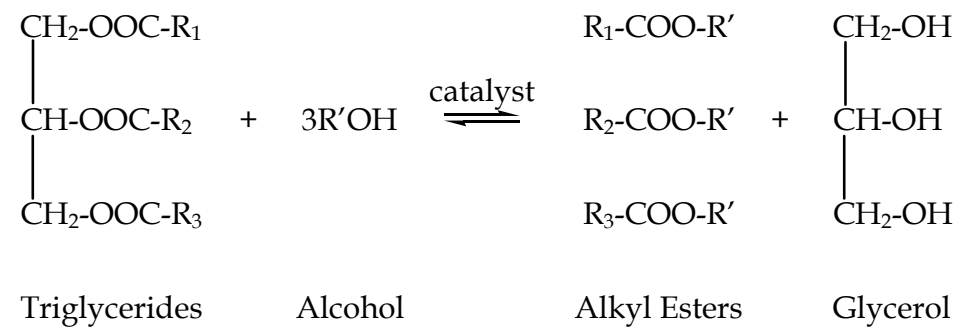

Fig. 2. Transesterification of triglyceride with alkyl alcohol (Komintarachat \& Chuepeng, 2009)

To prepare biodiesel, the most commonly used process is the base catalyst (e.g. sodium hydroxide, $\mathrm{NaOH}$ ) reaction (Graboski \& McCormick, 1998), due to its cost effectiveness and reaction stability. Biodiesel is produced through a transesterification from pure oils (Van Gerpen et al., 2004). In the transesterification simply depicted in Fig. 2, feedstock in forms of triglycerides reacts with methanol in the presence of a catalyst to yield fatty acid methyl ester (FAME) and by-products (Kinast, 2003). The by-products generally are glycerol, water, methanol and catalyst traces, and un-reacted triglycerides (Babu \& Devaradjane, 2003).

In the biodiesel production from waste used cooking oil (WCO), the methanol based transesterification over the synthesized solid acid catalyst at high free fatty acid (FFA) of $15 \% \mathrm{w} / \mathrm{w}$ was extensively studied by Komintarachat \& Chuepeng (2009). The type of porous support of the catalyst affected the amount of the FAME yield. Under the reaction conditions of $383 \mathrm{~K}$ temperature, 0.3 methanol/WCO weight ratio, $1.0 \% \mathrm{w} / \mathrm{w}$ catalyst to WCO ratio within 2-hour reaction time, it was found that the $\mathrm{WO}_{\mathrm{x}} / \mathrm{Al}_{2} \mathrm{O}_{3}$ support yielded the maximum FAME of $97.5 \%$ and the rest were in the following order: silicon oxide $\left(\mathrm{SiO}_{2}\right)>$ tin oxide $\left(\mathrm{SnO}_{2}\right)>$ zinc oxide $(\mathrm{ZnO})$. This is due to higher surface area and greater volume of the porous aluminum oxide support compared to the others.

The catalytic activities of conventional catalysts, i.e. potassium hydroxide $(\mathrm{KOH})$, potassium carbonate $\left(\mathrm{K}_{2} \mathrm{CO}_{3}\right)$, sulfuric acid $\left(\mathrm{H}_{2} \mathrm{SO}_{4}\right)$ with the $\mathrm{WO}_{x} / \mathrm{Al}_{2} \mathrm{O}_{3}$ catalyst under the optimum condition, previously mentioned were also compared and studied by Komintarachat \& Chuepeng (2009). The $\mathrm{WO}_{x} / \mathrm{Al}_{2} \mathrm{O}_{3}$ and $\mathrm{KOH}$ catalysts gave the highest activity by yielding the maximum FAME. However, the latter promotes soap formation which may be a problem on separation (Jitputti et al., 2006).

The conversion of WCO at $15.0 \% \mathrm{w} / \mathrm{w}$ FFA to biodiesel over potassium hydroxide $(\mathrm{KOH})$ catalyst through transesterification reactions was reported in Komintarachat \& Chuepeng (2010). The effects of alcohol and catalyst quantity, reaction time, and temperature on the FFA conversion and biodiesel production were studied. The optimum use of $5 \% \mathrm{w} / \mathrm{w} \mathrm{KOH}$ catalyst at $70^{\circ} \mathrm{C}$ for $2 \mathrm{~h}$ yielded $88.20 \%$ FFA conversion and $50 \%$ biodiesel recovery of WCO. It was observed that the produced biodiesel has exhibited the same functional group as of 
the biodiesel blend sold in local gas station. Summarily, the produced biodiesel may be used in diesel engines if other properties are tested for compatibility. This provides one more choice for alternative energy.

\subsection{Biodiesel standard}

The quality of biodiesel in Europe is described in the European Standard EN 14214 "Automotive fuels - Fatty acid methyl esters (FAME) for diesel engines - Requirements and test methods". Both neat biodiesel and its blend component are required to conform to this standard while requirements and test methods are shown in Table 2.

Neat biodiesel is named B100 and may be blended with fossil diesel. In case of the blend, it is designated as $\mathrm{BXX}$, where $\mathrm{XX}$ represents the volumetric percentage of neat biodiesel contained in the blend. In Directive 2003/30/EC (2003), biodiesel used for vehicles in pure form or as a blend should comply with the quality standard to ensure optimum engine performance.

\begin{tabular}{|l|c|c|c|c|}
\hline \multicolumn{1}{|c|}{ Property } & Unit & Minimum limit & Maximum limit & Test method \\
\hline Viscosity @ $40^{\circ} \mathrm{C}$ & $\mathrm{mm}^{2} \cdot \mathrm{s}^{-1}$ & 3.50 & 5.00 & ISO 3104 \\
\hline Flash point & ${ }^{\circ} \mathrm{C}$ & 120 & - & ISO 3679 \\
\hline Sulphate ash & $\% \mathrm{wt}$ & - & 0.02 & ISO 3987 \\
\hline Cetane number & & 51.0 & - & ISO 5165 \\
\hline Carbon residue & $\% \mathrm{wt}$ & - & 0.30 & ISO 10370 \\
\hline Acid value & $\mathrm{mg} \mathrm{KOH} \cdot \mathrm{g}-1$ & - & 0.50 & EN 14104 \\
\hline Total glycerol & $\% \mathrm{wt}$ & - & 0.25 & EN 14105 \\
\hline Oxidation stability $@ 110^{\circ} \mathrm{C}$ & $\mathrm{h}$ & 6.0 & - & EN 14112 \\
\hline Sulphur & $\mathrm{mg} \cdot \mathrm{kg}^{-1}$ & - & 10.0 & ISO $20846 / 84$ \\
\hline
\end{tabular}

Table 2. Requirements for fatty acid methyl ester

\section{Biodiesel properties}

Biodiesel fuels in the form of methyl or ethyl esters are oxygenated organic compounds that can be used in diesel engines as some of their properties are comparable to those of diesel. Table 3 shows the key properties of biodiesel derived from rapeseed oil (rapeseed methyl ester, RME) and ultra low sulphur diesel (ULSD) in comparison.

Biodiesel feedstock does not inherently contain sulphur but however, it may be present in biodiesel because of prior contamination during the transesterification process and in storage (EMA, 2003). Some other physical properties of biodiesel affect characteristics of the combustion in diesel engine such as density and viscosity (Rakopoulos \& Hountalas, 1996) and bulk modulus of compressibility (Tat \& Van Gerpen, 2002; Boehman et al., 2004). The bulk modulus of compressibility of biodiesel (property not shown in Table 3 ) is higher than that of fossil diesel. This yields better fuel atomisation by increasing the number and shifting the fuel droplets to smaller sizes. Generally, the bulk modulus of compressibility is a function of injection pressure. This suggests that the pressure in the pump-line-injector fuel system with biodiesel fuelling can be built-up and distributed faster even at the same pump timing (Szybist \& Boehman, 2003). 


\begin{tabular}{|l|c|c|c|c|}
\hline \multicolumn{1}{|c|}{ Fuel analysis } & Unit & Test method & $\begin{array}{c}\text { Ultra low } \\
\text { sulphur diesel }\end{array}$ & $\begin{array}{c}\text { Rapeseed } \\
\text { methyl ester }\end{array}$ \\
\hline Viscosity at $40^{\circ} \mathrm{C}$ & $\mathrm{cSt}$ & ASTM D445 & 2.467 & 4.478 \\
\hline Density at $15^{\circ} \mathrm{C}$ & $\mathrm{kg} \cdot \mathrm{m}^{-3}$ & ASTM D4052 & 827.1 & 883.7 \\
\hline Cetane number & & ASTM D613 & 53.9 & 54.7 \\
\hline Lower heating value & $\mathrm{MJ} \cdot \mathrm{kg}^{-1}$ & & 42.7 & 39.0 \\
\hline Sulphur & $\mathrm{mg} \cdot \mathrm{kg}^{-1}$ & ASTM D2622 & 46 & 5 \\
\hline Molecular weight & & & 209 & 296 \\
\hline $50 \%$ distillation & ${ }^{\circ} \mathrm{C}$ & & 264 & 335 \\
\hline $90 \%$ distillation & ${ }^{\circ} \mathrm{C}$ & & 329 & 342 \\
\hline Carbon & $\% \mathrm{wt}$ & & 86.5 & 77.2 \\
\hline Hydrogen & $\% \mathrm{wt}$ & & 13.5 & 12.0 \\
\hline Oxygen & $\% \mathrm{wt}$ & & - & 10.8 \\
\hline
\end{tabular}

Table 3. Fuel properties (Chuepeng et al., 2007)

\section{Biodiesel-fuelled engine performance}

In general, typical heating value for biodiesel is lower than that of fossil diesel (see Table 3). A greater amount of fuel is subsequently required to maintain the same engine brake torque. Greater fuel consumption of up to $13 \%$ by the use of D-2 diesel-biodiesel mixture were reported with heavy-duty engines over the United States Federal Test Procedure (USFTP) cycle (Sharp et al., 2000a). However, the energy efficiency is independent of fuel consumption (Graboski et al., 1996).

The engine power is dependent upon the energy density stored in the fuel (Chuepeng, 2008). Sharp et al. (2000a) revealed their findings that $8 \%$ and $2 \%$ engine power losses are measured with neat biodiesel and B20 blends, respectively. In addition, Graboski et al. (1996) found the reduction in maximum torque respective to the increase of biodiesel blend in a D-2 diesel. The brake torque from the combustion of neat biodiesel is lower by $5.4 \%$ compared to that from pure D-2 diesel which is in good agreement as expected from the energy density ratio of the two base fuels. However, Senatore et al. (2000) found that the engine torque and performance are substantially unaffected when comparing in terms of equivalence ratio.

\section{Combustion characteristics of biodiesel and its blends}

Both physical and chemical properties can affect combustion characteristics of biodiesel and its blends. The biodiesel blends combustion increases the average peak cylinder pressure due to the shorter ignition delay over the baseline diesel combustion (Chuepeng, 2008). The advanced injection timing and increased injection pressure (and thereby increased fuel injection rate) have been frequently reported for the use of biodiesel (Szybist \& Boehman, 2003). The main reasons are due to their differences in density (Rakopoulos \& Hountalas, 1996) and bulk modulus of compressibility (Boehman et al., 2004).

Chuepeng et al. (2007) studied quantitative impacts on combustion characteristics and exhaust emissions by the use of high proportion biodiesel blends. Fuel mixtures of $0 \%, 25 \%$ and 50\% RME by volume in ULSD were experimentally investigated in a single cylinder diesel engine in terms of the effects of engine load, exhaust gas recirculation (EGR) rate, and 
injection timing. By keeping engine with the same load, the RME blends increased proportion of the fuel burnt in the premixed phase and the combustion is advanced to earlier crank angle positions, with shortened ignition delay and increased peak cylinder pressure. Increasing the EGR rate of up to $20 \%$ at the same load and speed appeared to reduce peak pressure slightly and increase ignition delay, for all tested fuels. Without EGR, the SOI was studied by advancing and retarding by $2{ }^{\circ} \mathrm{CA}$ from the standard injection timing $\left(22^{\circ} \mathrm{CA} \mathrm{BTDC}\right)$. For the same blended fuel, the retarded SOI lowered peak pressure and shorter ignition delay for all tested fuels, and the adverse effects were observed with advanced SOI.

\section{Combustion-generated emissions}

Without exhaust catalyst and timing change, common trends of exhaust gas emissions from a stock engine fuelled with neat or blended biodiesel are (1) increased $\mathrm{NO}_{x},(2)$ decreased $\mathrm{PM}, \mathrm{CO}$, and $\mathrm{HC}$, and (3) decreased soot (solid carbon fraction of PM) mass emission (Lapuerta et al., 2008). Summarily, biodiesel and its blends mostly reduce engine emissions compared to fossil diesel, while the only regulated emission shown to increase consistently with biodiesel is $\mathrm{NO}_{\mathrm{x}}$. There are three main strategies to mitigate the increasing engine $\mathrm{NO}_{\mathrm{x}}$ :

- Determining biodiesel properties which can be modified to lower $\mathrm{NO}_{\mathrm{x}}$ emissions or modifying fuel properties using a proper base fuel and additives for biodiesel blending (McCormick et al., 2002).

- Improving combustion chamber design to inhibit $\mathrm{NO}_{\mathrm{x}}$ production by lowering combustion temperatures.

- Calibrating the engine when using biodiesel fuel. $\mathrm{NO}_{\mathrm{x}}$ can be controlled by tuning injection strategy to optimise all engine outputs specifically for biodiesel (Postrioti et al., 2003).

For other unregulated emissions from an engine fuelled with biodiesel, polycyclic aromatic hydrocarbon $(\mathrm{PAH})$ and nitro $\mathrm{PAH}$ compounds are substantially reduced, as well as the lower levels of some toxic and reactive HC species (Sharp et al., 2000b).

The PM composition (i.e. volatile material and elemental carbon) from the combustion of RME-based biodiesel blend (B30) in a turbo-charged engine with EGR operation was studied using thermo-gravimetric analysis (TGA) (Chuepeng et al., 2008a). Generally, total PM mass from B30 combustion was lower than that for diesel in all engine operating conditions. Elemental carbon PM mass fractions were slightly lower for the B30. The volatile material portions of the B30 particulates are greater than those of diesel particulates irrespective of engine operating condition. For both fuels used in the test, volatile material was observed to be higher at idle speed and light load when exhaust gases were at low temperature. For other carbonaceous emissions, the combustion of B30 tends to reduce visible smoke, $\mathrm{HC}$ and $\mathrm{CO}$ emissions.

For particle number size characterisation, Tsolakis (2006) examined the exhaust PM from a single cylinder diesel engine equipped with pump-line-injector fuel system and fuelled with neat biodiesel. The particle size distributions were found to be affected by the use of EGR. The results previously obtained were consistent with those conducted by Chuepeng et al. (2008b) using a V6 diesel engine equipped with a common rail fuel injection system. In summary, the particle size of B30 combustion aerosol without EGR is smaller than that of diesel while giving higher number concentration. When EGR were in use, the total particle number and mass were increased along with the increase in particle size for both B30 and 
diesel. The total calculated particle masses of B30 combustion aerosol are lower than those of the diesel case (Chuepeng et al., 2009). This confirms the results obtained by the TGA previously mentioned.

\section{Emission control technology for biodiesel-fuelled engine}

Emission control technology for biodiesel-fuelled engine is composed of two main ideas, i.e. engine and after-treatment technologies. These have been tested and widely introduced to diesel engine vehicles. For the engine technology, two popular methods comprise fuel injection strategy (both fuel injection timing and pressure) and EGR. With the advent of advance technology in electro-mechanics, the common rail fuel injection system can accomplish splitting fuel injection, choosing injection event and timing, and controlling injection pressure. By this way, the rate shaping strategies of the fuel injection are controllable (Mahr, 2002). The $\mathrm{NO}_{\mathrm{x}}$ emissions can be reduced using pre-injection with small amount of fuel; this prevents a long period of ignition delay, resulting a reduction of peak pressure occurred when the premixed fuel combusts.

Technology from research on $\mathrm{NO}_{x}$ emission reduction by the use of EGR is obviously effective. The reduction of the in-cylinder global temperature by the EGR is the main reason for the $\mathrm{NO}_{x}$ reduction. The research work by Andree \& Pachernegg (1969) has shown impacts on ignition conditions as oxygen concentration is decreased due to the dilution by EGR. In addition, Ladommatos et al. (1998) also revealed that the reduction in combustion temperature is a consequence of the reduced peak rate of the premixed phase combustion due to the lower oxygen availability when EGR is applied.

\section{Other automotive applications of biodiesel}

Biodiesel is not only used as a fuel for automotive fuel, but also used for other automotive application: for example, exhaust gas-assisted fuel reforming. This manner is a way to produce hydrogen on-board in stead of carrying a massive hydrogen vessel in the vehicle for combusted in engine. This exhaust gas emission control concept has been originally applied to SI engines (Jamal \& Wyszynski, 1994; Jamal et al., 1996). In a catalytic reformer, the exhaust gas reforming process takes place by injecting a portion of fresh fuel (reformer fuel) to react with an extracted exhaust gas stream to generate a hydrogen-rich reformed exhaust gas which is routed to mix with fresh intake charge before entering the engine combustion chamber; this method is called reformed exhaust gas recirculation (REGR).

Similarly to the gasoline reforming, in a diesel engine, hydrogen is generated using a direct catalytic interaction of hydrocarbon fuel with partial exhaust gases at sufficiently high temperatures with plenty of oxygen and steam (unlike gasoline exhaust). Tsolakis et al. (2003) firstly studied on an open-loop engine reformer system. The addition of EGR in combination with small amounts of hydrogen was found to affect the combustion and exhaust gas emissions. The added hydrogen replaced the main injected fossil diesel and maintained the same engine load, resulting in simultaneous reductions of both smoke and $\mathrm{NO}_{x}$ emissions without significant impacts on engine efficiency.

A feasibility study on producing hydrogen on-board from biodiesel by catalytic exhaust gas fuel reforming was carried out using a laboratory reforming mini reactor. Tsolakis \& 
Megaritis (2004b) experimentally studied the reforming of RME-based biodiesel and diesel in comparison and had found that the former produced more hydrogen (up to 17\%) with higher fuel conversion efficiency. The appropriated addition of reformer fuel and water to the reformer promotes reactions, yielding more hydrogen production even in the low temperature diesel exhaust gas conditions (Tsolakis \& Megaritis, 2004a). Though the reformer fuel added to produce REGR is required, the produced hydrogen-rich gas, substituting part of the main engine fuel resulted in improved fuel economy, during closeloop engine-reformer operation (Tsolakis et al., 2005).

\section{Conclusion}

Biodiesel is oxygenated ester compounds produced from a variety sources of feedstock such as vegetable oils, animal fats, or waste cooking oils. Biodiesel is widely use as a part substitute for fossil diesel in the present day due to its comparable properties to those of fossil diesel. The use of biodiesel blends in diesel engines has affected engine performance as well as combustion characteristics, i.e. ignition delay, injection timing, peak pressure, heat release rate, and so on. This results in different composition and amounts of both engine exhaust gaseous and non-gaseous emissions. The combustion of biodiesel in diesel engines has normally improved the most regulated emissions except nitrogen oxides emissions. However, there are techniques to mitigate this problem, e.g. exhaust gas recirculation and exhaust gas-assisted fuel reforming. One of the main serious problems in diesel engines is smoke emissions especially particulate mass which can be dramatically reduced by the use of biodiesel. Summarily, with the advent of advanced engine control technology, it is prospective in using biodiesel as an alternative not only combusted in internal combustion engines but also used in other automotive applications.

\section{References}

Andree, A. \& Pachernegg, S.J. (1969) Ignition conditions in diesel engines. Society of Automotive Engineering Transaction, Vol. 78, No. 2, pp. 1082-1106

Babu, A.K. \& Devaradjane, G. (2003) Vegetable oils and their derivatives as fuels for CI engine: an overview, Society of Automotive Engineers, Paper No. 2003-01-0767

Boehman, A.L., Morris, D. \& Szybist, J. (2004) The impact of the bulk modulus of diesel fuels on fuels injection timing. Energy \& Fuels, Vol. 18, pp. 1877-1882

Bosch. (2005) Diesel-engine management systems and components (4th ed.), John Wiley, ISBN 0470-02689-8, West Sussex

Camobreco, V., Sheehan, J., Duffield, J. \& Graboski, M. (2000) Understanding the lifecycle costs and environmental profile of biodiesel and petroleum diesel fuel, Society of Automotive Engineers, Paper No. 2000-01-1487

CEC (2000) Green paper: towards a European strategy for the security of energy supply, Commission of the European Communities, Brussels

Chuepeng, S., Tsolakis, A., Theinnoi, K., Xu, H.M., Wyszynski, M.L. \& Qiao, J. (2007) A study of quantitative impact on emissions of high proportion RME-based biodiesel blends, Society of Automotive Engineers, Paper No. 2007-01-0072 
Chuepeng, S. (2008) Quantitative impact on engine performance and emissions of high proportion biodiesel blends and the required engine control strategies, $\mathrm{PhD}$ Thesis, The University of Birmingham

Chuepeng, S., Xu, H.M., Tsolakis, A., Wyszynski, M.L., Price, P., Stone, R., Hartland, J.C. \& Qiao, J. (2008a) Particulate emissions from a common rail fuel injection diesel engine with RME-based biodiesel blended fuelling using thermo-gravimetric analysis, Society of Automotive Engineers, Paper No. 2008-01-0074

Chuepeng, S., Theinnoi, K., Tsolakis, A., Xu, H.M., Wyszynski, M.L., York, A.P.E., Hartland, J.C., \& Qiao, J. (2008b) Investigation into particulate size distributions in the exhaust gas of diesel engines fuelled with biodiesel blends. Journal of KONES Powertrain and Transport, Vol. 15, No. 3, pp. 75-82

Chuepeng, S., Xu, H.M., Tsolakis, A., Wyszynski, M.L., \& Hartland, J.C. (2009) Nano-particle number from biodiesel blends combustion in a common rail fuel injection system diesel engine equipped with exhaust gas recirculation. Combustion Engines, Vol. 138 , No. 3, pp. $28-36$

Directive 2003/30/EC (2003) The promotion of the use of biofuels or other renewable fuels for transport. Official Journal of the European Union, Vol. L123, pp. 42-46

EMA (2003) Technical statement on the use of biodiesel fuel in compression ignition engines, Date of access 23 June 2011, Available from: http://www.reefuel.com/ data/info/EMA_Position_on_Biodiesel_Use_Mar_2003.pdf

Ferguson, C.R. (1986) Internal combustion engines: applied thermosciences, John Wiley, ISBN 0471-88129-5, Newyork

Filipi, Z., Wang, Y. \& Assanis, D. (2001) Effect of variable geometry turbine (VGT) on diesel engine and vehicle system transient response, Society of Automotive Engineers, Paper No. 2001-01-1247

Flaig, U., Polach, W. \& Ziegler, G. (1999) Common rail system (CR-system) for passenger car DI diesel engines: experiences with applications for series production projects, Society of Automotive Engineers, Paper No. 1999-01-0191

Graboski, M.S., Ross, J.D. \& McCormick, R.L. (1996) Transient emissions from no. 2 diesel and biodiesel blends in a DDC series 60 engine, Society of Automotive Engineers, Paper No. 961166

Graboski, M.S. \& McCormick, R.L. (1998) Combustion of fat and vegetable oil derived fuels in diesel engines. Progress in Energy and Combustion Science, Vol. 24, pp. 125-164

Hashizume, T., Miyamoto, T., Akagawa, H. \& Tsujimura, K. (1998) Combustion and emission characteristics of multiple stage diesel combustion, Society of Automotive Engineers, Paper No. 980505

Heywood, J.B. (1988) Internal combustion engine fundamentals, McGraw-Hill, ISBN 0-07100499-8, Singapore

Ibara, T., Lida, M. \& Foster, D.E. (2006) Study on characteristics of gasoline fueled HCCI using negative valve overlap, Society of Automotive Engineers, Paper No. 2006-320047

Jamal, Y. \& Wyszynski, M.L. (1994) On-board generation of hydrogen-rich gaseous fuels-A review. International Journal of Hydrogen Energy, Vol. 19, pp. 557-572 
Jamal, Y., Wagner, T. \& Wyszynski, M.L. (1996) Exhaust gas reforming of gasoline at moderate temperatures. International Journal of Hydrogen Energy, Vol. 21, No. 6, pp. 507-519

Jitputti, J., Kitiyanan, B., Rangsunvigit, P., Bunyakiat, K., Attanatho, L. \& Jenvanitpanjakul, P. (2006) Transesterification of crude palm kernel oil and crude coconut oil by different solid catalysts. Chemical Engineering Journal, Vol. 116, pp. 61-66

Kalam, M.A. \& Masjuki, H. (2005) Emissions and deposits characteristics of a small diesel engine when operated on preheated crude palm oil, Society of Automotive Engineers, Paper No. 2005-01-3697

Kimura, S., Aoki, O., Kitahara, Y. \& Aiyoshizawa, E. (2001) Ultra-clean combustion technology combining a low-temperature and premixed combustion concept for meeting future emission standards. Society of Automotive Engineers Transaction, Vol. 110, No. 4, pp. 239-246

Kinast, M.A. (2003) Production of biodiesels from multiple feedstocks and properties of biodiesel and biodiesel/diesel blends, Date of access 23 June 2011, Available from: http://www.nrel.gov/docs/fy03osti/31460.pdf

Komintarachat, C. \& Chuepeng, S. (2009) Solid acid catalyst for biodiesel production from waste used cooking oils. Industrial E Engineering Chemistry Research, Vol. 48, pp. 9350-9353

Komintarachat, C. \& Chuepeng, S. (2010) Methanol-based transesterification optimization of waste used Ccooking oil over potassium hydroxide catalyst. American Journal of Applied Sciences, Vol. 7, No. 8, pp. 1073-1078

Kumar, M.S., Ramesh, A. \& Nagalingam, B. (2003) Use of hydrogen to enhance the performance of a vegetable oil fuelled compression ignition engine. International Journal of Hydrogen Energy, Vol. 28, pp. 1143-1154

Klingbeil, A.E., Juneja, H., Ra, Y. \& Reitz, R.D. (2003) Premixed diesel combustion analysis in a heavy-duty diesel engine, Society of Automotive Engineers, Paper No. 2003-01-0341

Ladommatos, N., Abdelhalim, S.M., Zhao, H. \& Hu, Z. (1998) Effects of EGR on heat release in diesel combustion, Society of Automotive Engineers, Paper No. 980184

Lapuerta, M., Armas, O. \& Rodíguez-Fernández, J. (2008) Effect of biodiesel fuels on diesel engine emissions. Progress in Energy and Combustion Science, Vol. 34, pp. 198-223

Mahr, B. (2002) Future and potential of diesel injection systems, THIESEL 2002 Conference on Thermo- and Fluid- Dynamic Processes in Diesel Engines, pp. 5-17

McCormick, R.L., Alvarez, J.R., Graboski, M.S., Tyson, K.S. \& Vertin, K. (2002) Fuel additive and blending approaches to reducing $\mathrm{NO}_{x}$ emissions from biodiesel, Society of Automotive Engineers, Paper No.2002-01-1658

Oguma, M., Goto, S., Konno, M., Sugiyama, K. \& Mori, M. (2002) Experimental study of direct injection diesel engine fuelled with two types of gas to liquid (GTL), Society of Automotive Engineers Transaction, Vol. 111, No. 4, pp. 1214-1220

Postrioti, L., Battistoni, M., Grimaldi, C.N. \& Millo, F. (2003) Injection strategies tuning for the use of bio-derived fuels in a common rail HSDI diesel engine, Society of Automotive Engineers, Paper No. 2003-01-0768 
Quirin, M., Gärtner, S.O., Pehnt, M. \& Reinhardt, G.A. (2004) $\mathrm{CO}_{2}$ mitigation through biofuels in the transport sector: status and perspective, Date of access 23 June 2011, Available from: http://www.biodiesel.org/resources/reportsdatabase/reports/gen/ 2004 0801_gen-351.pdf

Rakopoulos, C.D. \& Hountalas, D.T. (1996) A simulation analysis of a DI diesel engine fuel injection system fitted with a constant pressure valve. Energy Conversion and Management, Vol. 37, No. 2, pp. 135-150

Sharp, C.A., Howell, S.A. \& Jobe, J. (2000a) The effect of biodiesel fuels on transient emissions from modern diesel engines, part I regulated emissions and performance, Society of Automotive Engineers, Paper No. 2000-01-1967

Sharp, C.A., Howell, S.A. \& Jobe, J. (2000b) The effect of biodiesel fuels on transient emissions from modern diesel engines, part II unregulated emissions and chemical characterization. Society of Automotive Engineers Transaction, Vol. 109, No. 4, pp. 1784-1807

Senatore, A., Cardone, M., Rocco, V. \& Prati, M.V. (2000) A comparative analysis of combustion process in DI diesel engine fuelled with biodiesel and diesel fuel, Society of Automotive Engineers, Paper No. 2000-01-0691

Szybist, J.P. \& Boehman, A.L. (2003) Behavior of a diesel injection system with biodiesel fuel, Society of Automotive Engineers, Paper No. 2003-01-1039

Tat, M.E. \& Van Gerpen, J.H. (2002) Physical properties and composition detection of biodiesel - diesel fuel blends, American Society of Agricultural and Biological Engineers, Paper No. 026084

Tsolakis, A. (2006) Effects on particulate size distribution from the diesel engine operating in RME-biodiesel with EGR. Energy \& Fuels, Vol. 20, pp. 1418-1424

Tsolakis, A., Megaritis, A. \& Wyszynski, M.L. (2003) Application of exhaust gas fuel reforming in compression ignition engines fuelled by diesel and biodiesel fuel mixtures. Energy \& Fuels, Vol. 17, pp. 1464-1473

Tsolakis, A. \& Megaritis, A. (2004a) Catalytic exhaust gas fuel reforming for diesel engineseffect of water additional on hydrogen production and fuel conversion efficiency. International Journal of Hydrogen Energy, Vol. 29, pp. 1409-1419

Tsolakis, A. \& Megaritis, A. (2004b) Exhaust gas assisted reforming of rapeseed methyl ester for reduced exhaust emissions of CI engines. Biomass and Bioenergy, Vol. 27, pp. 493-505

Tsolakis, A. \& Megaritis, A. (2004c) Exhaust gas fuel reforming for diesel engines- A way to reduce smoke and $\mathrm{NO}_{x}$ emissions simultaneously, Society of Automotive Engineers, Paper No. 2004-01-1844

Tsolakis, A., Megaritis, A., Yap, D. \& Abu-Jrai, A. (2005) Combustion characteristics and exhaust gas emissions of a diesel engine supplied with reformed EGR, Society of Automotive Engineers, Paper No. 2005-01-2087

Weall, A. \& Collings, N. (2007) Investigation into partially premixed combustion in a lightduty multi-cylinder diesel engine fuelled with a mixture of gasoline and diesel, Society of Automotive Engineers, Paper No. 2007-01-4058 
Van Gerpen, J.H., Shanks, B., Pruszko, R., Clements, D. \& Knothe, G. (2004) Biodiesel production technology: August 2002 - January 2004, Date of access 23 June 2011, Available from: http://www.nrel.gov/docs/fy04osti/36244.pdf 


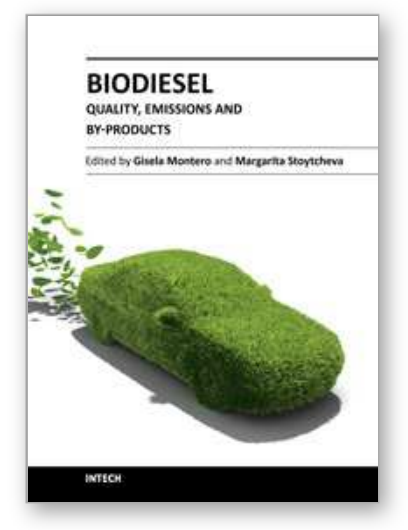

\author{
Biodiesel- Quality, Emissions and By-Products \\ Edited by Dr. Gisela Montero
}

ISBN 978-953-307-784-0

Hard cover, 380 pages

Publisher InTech

Published online 16, November, 2011

Published in print edition November, 2011

This book entitled "Biodiesel: Quality, Emissions and By-products" covers topics related to biodiesel quality, performance of combustion engines that use biodiesel and the emissions they generate. New routes to determinate biodiesel properties are proposed and the process how the raw material source, impurities and production practices can affect the quality of the biodiesel is analyzed. In relation to the utilization of biofuel, the performance of combustion engines fuelled by biodiesel and biodiesels blends are evaluated. The applications of glycerol, a byproduct of the biodiesel production process as a feedstock for biotechnological processes, and a key compound of the biorefinery of the future is also emphasized.

\title{
How to reference
}

In order to correctly reference this scholarly work, feel free to copy and paste the following:

S. Chuepeng (2011). The Use of Biodiesel in Diesel Engines, Biodiesel- Quality, Emissions and By-Products, Dr. Gisela Montero (Ed.), ISBN: 978-953-307-784-0, InTech, Available from:

http://www.intechopen.com/books/biodiesel-quality-emissions-and-by-products/the-use-of-biodiesel-in-dieselengines

\section{INTECH}

open science | open minds

\section{InTech Europe}

University Campus STeP Ri

Slavka Krautzeka 83/A

51000 Rijeka, Croatia

Phone: +385 (51) 770447

Fax: +385 (51) 686166

www.intechopen.com

\section{InTech China}

Unit 405, Office Block, Hotel Equatorial Shanghai

No.65, Yan An Road (West), Shanghai, 200040, China

中国上海市延安西路65号上海国际贵都大饭店办公楼 405 单元

Phone: +86-21-62489820

Fax: $+86-21-62489821$ 
(C) 2011 The Author(s). Licensee IntechOpen. This is an open access article distributed under the terms of the Creative Commons Attribution 3.0 License, which permits unrestricted use, distribution, and reproduction in any medium, provided the original work is properly cited. 